\title{
Change to Competence-Based Education in Structural Engineering
}

\author{
Enrique de Justo ${ }^{1}$ and Antonio Delgado ${ }^{2}$
}

\begin{abstract}
The launching of the European Higher Education Area (EHEA) in 2010 has imposed new challenges on European universities. Traditional teaching methods, based on lectures and examinations, are no longer suited for the new EHEA educational approach, now focused on competences development. Instead, active learning methods as Problem-based learning are far more appropriate. This paper examines the effect of a change to competence-based education through Problem-based learning (PBL) in the field of Structural Engineering, carried out in a first year structures course. The structures program design is described, with details of the PBL implementation. A program evaluation based on students' and faculty surveys is carried out. The evaluation results show that the program has been effective in the achievement of the proposed objectives. The benefits of the new approach include an increase in students' motivation and a better integration with other Architecture disciplines. The main challenges encountered are the increase in faculty time commitment and the academic resistance to change. Extrapolation to other disciplines is possible, although it requires restructuring of subject knowledge and methods.
\end{abstract}

Subject headings: - Engineering education; Teaching methods; Structural engineering; Structural analysis; Structural design.

Keywords: - Problem-based learning; European Higher Education Area; Competence-based education; Active learning, Student-centered learning; Structural Engineering education; Architectural Engineering; Structural analysis teaching; Structural design teaching.

\footnotetext{
${ }^{1}$ Professor Dept. of Building Structures, Univ. of Seville, Avda Reina Mercedes no 2, 41012 Seville, Spain (corresponding author). E-mail: ejem@us.es.

${ }^{2}$ Professor Dept. of Building Structures, Univ. of Seville, Avda Reina Mercedes no 2, 41012 Seville, Spain. Email: antoniodelga@us.es
}

How to cite: Justo, E. \& Delgado, A. (2014). Change to Competence-Based Education in Structural Engineering. Journal of Professional Issues in Engineering Education and Practice, D.O.I.: 10.1061/(ASCE)El.1943$5541.0000215,05014005$. 


\section{Background and Objectives}

In March 2010, the European Higher Education Area (EHEA) was launched in 48 countries, prompting for a radical shift in the teaching model of European Universities (Ministerio de Educación 2007, p. 44037). The new model was to be centered in what the students do (student-centred learning) with the teacher acting not as the source of knowledge, but rather as a facilitator in the learning process. The degree programs, based upon carefully defined professional profiles, are now focused in the acquisition of a set of competencies, involving the effective use of knowledge and skills in complex contexts (Westera, 2001, p. 79). Besides the subject-specific competences, which are discipline-related, a set of generic competences such as problem solving or teamwork skills are equally addressed in the new curricula.

In congruence with the principles outlined in the new model, the European Credit transfer System (ECTS) was adopted for the recognition of studies. It is based on the full students' workload and not restricted, as before, to contact hours only (European Commission 2009). Moreover, the traditional teaching and assessment methods, that proved useful for the acquisition of contents, are not effective for the development of competences. Instead, active learning methods, in which students engage in educational experiences that resemble professional practice as much as possible, are much more appropriate (Kirschner et al. 1997, p. 161).

Structural Engineering is a core discipline in the Engineering and Architecture schools in Spain with a pedagogical tradition that emphasize the use of lectures and written examinations. Historically, Structural Engineering courses exhibit high failure rates, which represent a strong argument in favor of the exploration of new forms of teaching.

A growing interest in active learning methods, such as Problem-based learning (PBL), can be observed in the Engineering Education literature (Felder et al. 2000, p. 8; Prince 2004). Several authors have emphasized the need for studies exploring the effectiveness of new approaches to learning that could be used in a context of competences acquisition (Walker and Leary 2009, p. 27; Van Barneveld and Strobel 2009, p. 42; Beddoes et al. 2010, p. 17). Recent contributions in this journal have addressed the implementation of PBL in the field of Structural Engineering (Solis et al. 2012; Queen and Albano 2008). The first case represents an example of partial implementation of the method, in which the PBL principles are mixed with traditional course objectives or assessment tools. In the second case, the 
experience was limited to a single student. Other authors (Fernández-Sánchez and Millán 2013; Mosalam et al. 2013) have reported on the application of more general hands-on strategies to Structural Engineering courses, but they lack the methodological framework that supports PBL.

This paper examines the effect of a change to competence-based education through Problem-based learning in the field of Structural Engineering, implemented in a first year 6 ECTS structures course in the School of Architecture of Seville (Spain). The experience reached a total of 324 students, divided in 12 groups. The benefits of such a paradigm shift are highlighted, as long as the main challenges faced in the implementation process. Finally, conclusions are drawn that may prove useful to extrapolate the experience to other Engineering contexts.

\section{Competences: Definition and Relevance}

The concept of competence is not straightforward, and has frequently led to confusion (Westera 2001, p. 75; Gonzalez and Wagenaar 2003, p. 24). We choose to define competence as the combination of knowledge, skills and attitudes that make it possible to perform an academic or professional action. This notion of competence implies knowledge associated to action. Accordingly, a competence-based curriculum is to be designed taking into account the kind of problems the graduates will have to face in their professional careers, which makes the new degree programs more professionally-oriented than the former ones.

The Tuning Project (González and Wagenaar, 2003) outlines the educational strategy for the new degree curriculums in the EHEA in terms of competences. Two kinds of competences are defined:

- Generic competences are those not associated to any discipline. They address common attributes that are useful in any subject area, such as problem solving, teamwork or the ability to communicate effectively.

- Subject-specific competences are those bound to a particular discipline. They concern the knowledge and methods that are relevant in the subject area.

The competences involve the application of knowledge and skills in complex contexts. By their nature, they can't be linked to a particular course or unit (González and Wagenaar 
2003 , p. 24). Instead, competences have to be developed through the whole curriculum, and are not expected to be achieved until the last courses of the program.

In addition to the concept of competences, the Tuning Project defines learning outcomes as statements of what a learner should know to do after the completion of a learning process (may be a unit, a course, or a cycle in a degree program). The learning outcomes of a course must be assessed at the end of the course; therefore they must be based on observable behaviors from the part of the learners.

Outside the European Union, many academic and professional institutions from the field of Engineering have also showed a growing interest in the competence-based approach over the last decade. In the United States, the Accreditation Board for Engineering and Technology (ABET), developed in 1996 a revised set of accreditation criteria, known as Engineering Criteria 2000 (ABET, 1997), which emphasized the acquisition of competences in response to claims from industry about the weaknesses of recent graduates in strategic capabilities, as communication skills or teamwork (Prados et al. 2005, p. 167-168).

\section{Problem-Based Learning}

Within a competence-based approach, the most effective instructional methods are active learning methods, especially those in which the educational experiences "resemble professional practice as much as possible" (Kirschner et al. 1997, p. 161). Among these, the Problem-based learning (PBL) method is particularly well suited to address both subjectspecific and generic competences (Felder and Brent 2003, p. 15).

\section{What is (and what is not) Problem-based learning?}

According to Barrows and Tamblyn (1980, p. 1), Problem-based learning is an instructional method in which "the learning results from the process of working toward the understanding or resolution of a problem". The problem, which has to be encountered first in the learning process, acts as the driver for the acquisition and integration of new knowledge.

In the field of Engineering, with a long tradition on the use of problem solving as a teaching method, Problem-based learning is often misunderstood, which results in underestimation of its value and possibilities as a learning tool for the acquisition of competences (SavinBaden 2000, p. 8). As Barrows and Tamblyn (1980, p. 2) point out: 
"There is nothing new about the use of problem solving as a method of learning in a variety of educational settings. Unlike what occurs in real life situations, however, the problem usually is not given to the students first, as a stimulus for active learning. It usually is given to the student after he has been provided with facts or principles, either as an example or as an exercise in which the student can apply this knowledge".

\section{Characteristics of PBL}

To be effective, a PBL learning environment must be designed according to a set of instructional principles (Savery and Duffy 1995, p. 3; Savin-Baden 2000, p. 17; De Graaff and Kolmos 2003, p. 657; Dolmans et al. 2005, p. 734; Svinicki 2007, p. 50; Schmidt et al. 2011, p. 793), derived from the constructivist theory:

1. The problem is the starting point and guides the learning process.

2. New knowledge is built upon the students' previous knowledge.

3. Students direct their own learning.

4. Students must collaborate to solve the problem.

5. It pays attention, not only to the products, but also to the processes of knowledge acquisition.

6. The solution of the problem is followed by reflection on both the content learned and the learning process.

7. Learning takes place under the guidance of a tutor/facilitator

8. The course must be organized around problems, not around contents.

\section{The tutorial session}

The PBL learning process is developed in two stages:

1. A first stage in which the students discuss the problem in groups, known as tutorial session.

2. An individual, self-directed study stage.

In the tutorial session, the group of students must reason through the problem, generate hypothesis, synthesize what they know and what they don't know about the problem, identify learning goals and formulate a plan that will guide the individual study of the group members (fig. 1). The tutor follows the group discussion but he (or she) will avoid giving information, thus only interacting with the group at a metacognitive level. For details on the implementation of a PBL tutorial session, see Uden and Beaumont (2006, p. 142-158). 
In our case, due to the number of students, it is not possible to have a tutor for each small group so we arranged a roving tutor moving between teams.

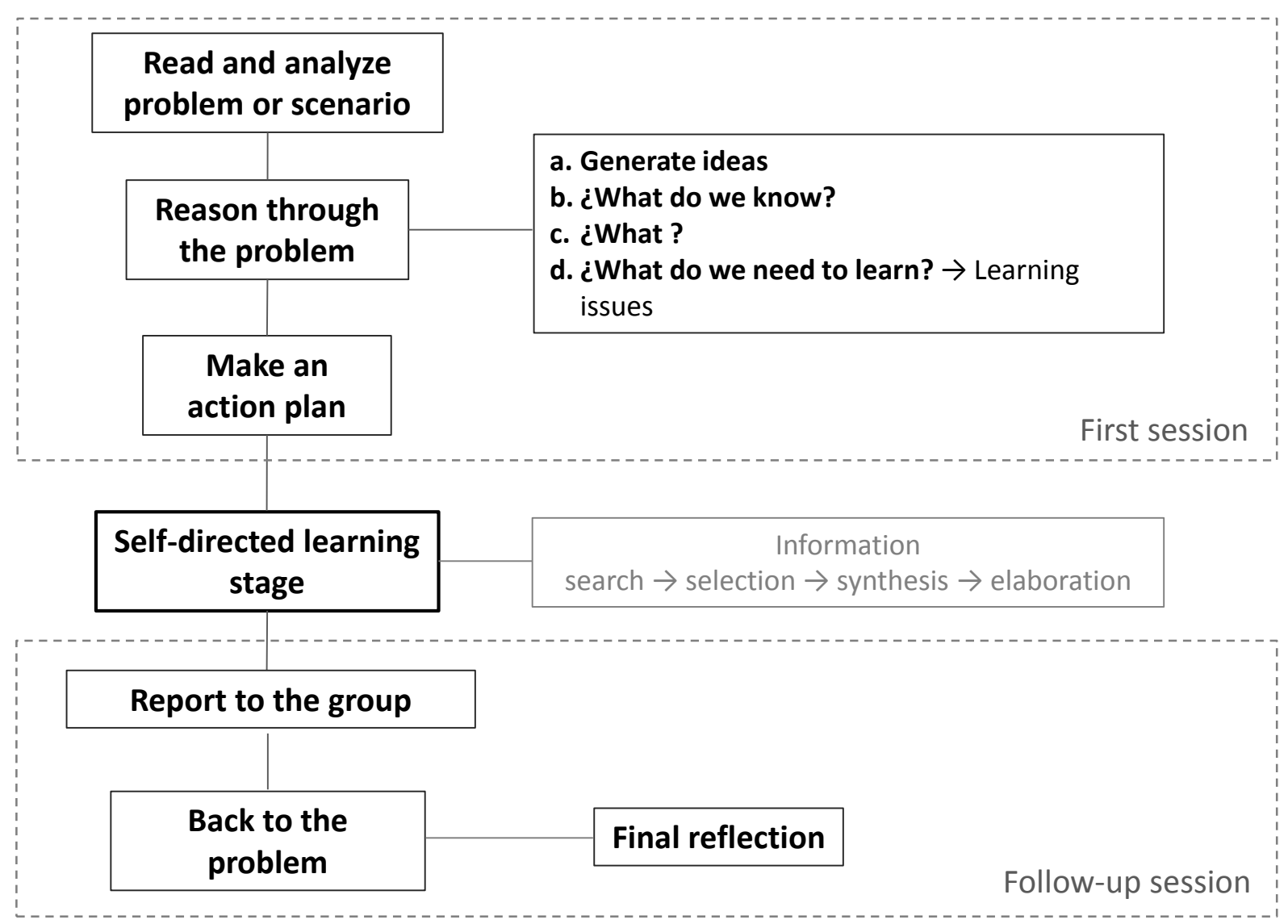

Figure 1. Stages in a tutorial session.

\section{Methodology}

Data collection and analysis was conducted through students and faculty surveys. The students' survey was carried out in the classroom at the end of the semester. 276 students completed the survey, representing $85 \%$ of the target population, which consisted of a total of 324 students enrolled in the course. The students answered a 30-item questionnaire. Items about satisfaction, self-evaluation of learning and workload are of particular interest to the present study. The reliability of student ratings for instructional evaluation has been widely accepted in the educational literature (Aleamoni, 1999). Descriptive statistics was applied in data analysis for course evaluation.

The faculty survey was responded by all faculty members teaching the course, a total of 4 full professors and 4 associate professors. 
Additionally, attendance data was collected from a mid-semester in-class survey, complemented with observation by faculty members. Academic achievement was measured through course grades.

\section{Program Overview}

\section{Brief historical perspective}

Historically, the introductory structures course at the school of Architecture of Seville (as in most of Architecture and Engineering schools) consisted essentially of a Strength of Materials program with a traditional teaching model based on lectures and examinations. The contact time was divided in:

- Lectures, where the theoretical concepts of the discipline were introduced, and the analysis methods explained.

- Problem solving classes, where calculation problems on simplified models of structures were demonstrated.

In the examinations, the students were prompted to solve by hand a set of calculation problems within a given time.

The Strength of Materials approach is faced with several limitations:

- Lack of relevance of the problems subject to study: due to the complexity of structural analysis methods, the repertoire of examples that can be calculated by hand is restricted to oversimplified models that don't represent the behavior of real Structures.

- The conception of analysis as an end in itself: the students spend the majority of the time doing repetitive calculations in simplified models. They merely obtain results, regardless of the implications of the analysis done in the overall structural design process.

- Lack of integration with other disciplines in the Architecture curriculum: the subject is taught in isolation from other areas of study, despite the importance granted to the integration of disciplines in any Architecture curriculum.

In spite of the oversimplification of the problems, the structural analysis discipline is still hard to grasp for students (Pedron 2006, p. 15; Goldfinch et al. 2008, p. 2), hence it is traditionally associated to high failure rates in the schools of Architecture and Engineering. In the School of Architecture of Seville, the structures programs had historically raised concerns among the academic responsibles of the institution, due on the one hand to low 
class attendance and success rate, and in the other hand to fragmented and surface learning, with difficulties to apply theory to practice.

The Strength of Materials approach, with lectures and examination, remained in place until the course 2010-11. Its outcomes were quite unsatisfactory. Table 1 shows success rate and attendance data in the course before the innovation was implemented.

\begin{tabular}{ll}
\hline Criteria & Rate \\
\hline Attendance rate (attending/enrolled) & $25.4 \%$ \\
\hline Success rate (passed/enrolled) & $35.5 \%$ \\
\hline Dropout rate (dropout/enrolled) & $46.8 \%$ \\
\hline
\end{tabular}

Table 1. Attendance and success rate data in the course Structures 1, with a traditional teaching approach.

\section{Basis of the program}

The starting point for the program planning process has been the set of requirements established by experts at four institutional levels (see fig. 2).

At the European level, the requirements of the EHEA should be applied: competence-based education, student-centred learning, ECTS credit system and the use of active learning methods.

At the national level, the white book for Architecture, published by the Spanish national accreditation agency (ANECA), sets the following curriculum recommendations for the Architecture degrees in Spain (ANECA 2005, pp. 178, 226, 299):

- The Architecture degrees must be oriented to a professional profile of General Architect.

- The actual duration of studies (currently estimated at 7 years) must be adjusted to the nominal duration (5 years).

- The main competence assigned to the structures courses in the Architecture degrees is "Structural Project", defined as the ability to conceive, design, analyze, integrate in buildings and urban environments, and execute a structural solution.

At the university level, the Architecture curriculum in the School of Architecture of Seville has been designed in accordance to the EHEA philosophy, featuring major changes with respect to previous versions:

- Eliminate distinction between theory and practice. 
- Implement continuous assessment (discouraging written examinations, except in exceptional circumstances).

- Reduce the students' ratio to 25-30 students per class.

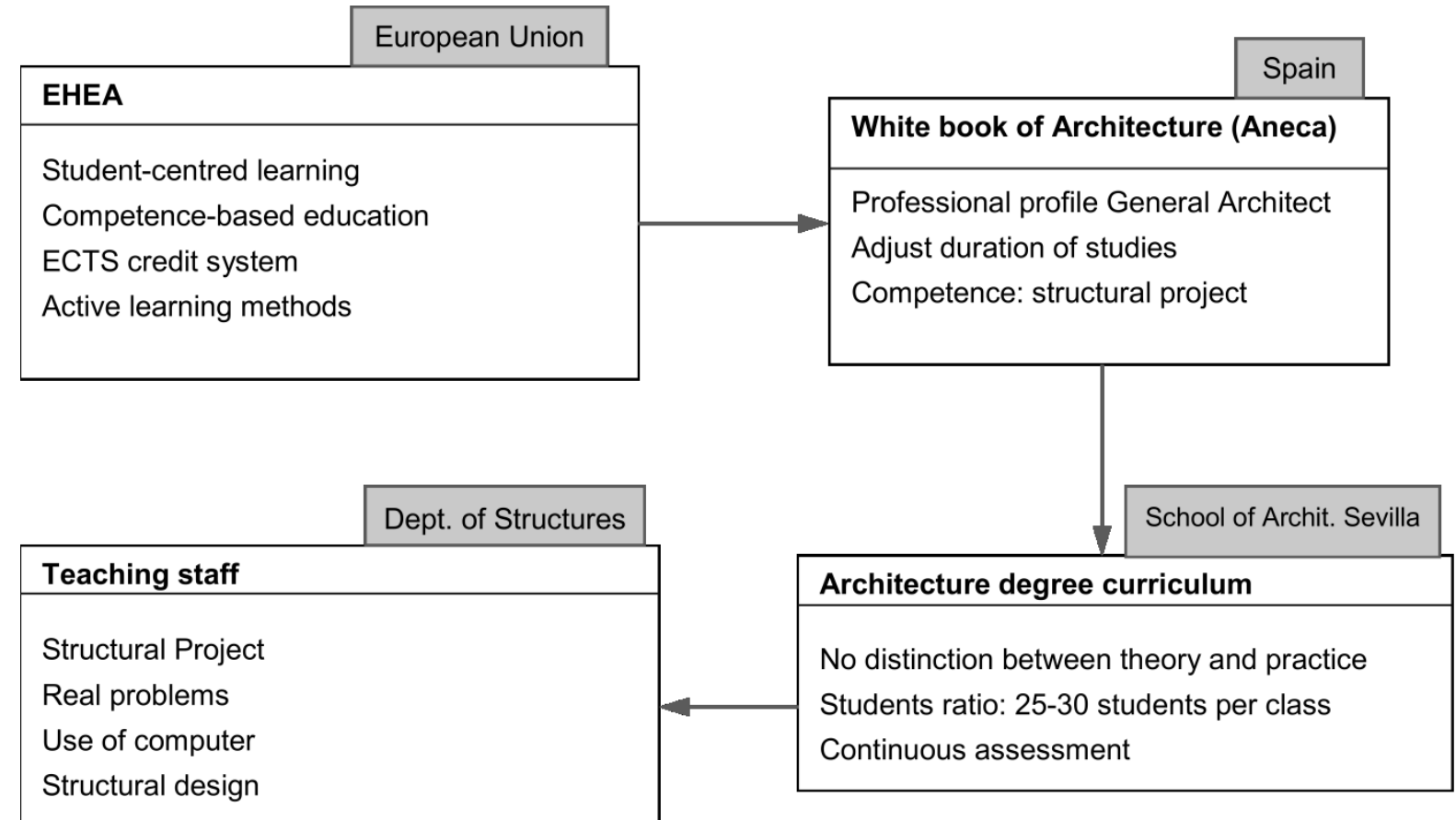

Fig 2. Course requirements at four different levels.

At the department level, the academic staff laid down the principles on which the introductory structures course should be based:

- The classic Strength of Materials approach, based entirely in repetitive hand calculations on simplified models, must be overcome.

- It is appropriate to introduce computer analysis, which will enable to work with real structures with a closer connection to Architecture.

- The first course must initiate students with the project of structures. The course contents should comprise: an introduction to structural types, actions on structures, analysis of simple post-and-beam structures and structural safety, including dimensioning and checking of structural elements.

- Analysis should be subordinated to design. The aim of any structural analysis should always be to evaluate the feasibility of a given design solution.

\section{Course objectives}

According to the Architecture curriculum, the acquisition of the competence "Structural Project" should be the main teaching goal of the structures courses. However, this 
competence will not be fully developed until the later stages of the curriculum (González and Wagenaar, 2003, p. 24). In the introductory course in structures, the competence is to be developed in simpler contexts, with a lower level of complexity. At this lower level the learning to be achieved in the course is specified in terms of learning outcomes:

a) Identify the structural types that are most common in buildings and describe its behavior and its integration in the overall design process.

b) Determine the values of the most frequent actions on structures.

c) Determine the behavior of a statically determinate structure by calculating reactions, internal forces, stresses and deformations.

d) Apply the limit states method in simple cases, regarding the structural requirements on equilibrium, strength and deformation.

e) Determine the behavior of a framework structure, using computer analysis software.

f) Analyze, in a schematic and introductory level, simple structures, building a structural model and using computer analysis software.

g) Design, in a schematic and introductory level, simple structures, in the context of an architectural design, with choice of material, structural type, geometry and joint connections.

In addition, a number of generic competences are assigned in the curriculum for development in the structures course:

- Ability to work in a team.

- Ability to work autonomously.

- Ability to resolve problems.

- Capacity for analysis and synthesis.

- Ability to apply knowledge in practical situations.

- Ability to plan and manage time.

Furthermore, in coherence with the educational basis of the course, some additional objectives had been set for achievement, namely:

- To reach high levels of students and faculty satisfaction.

- To achieve a success rate higher than $80 \%$.

- To increase significantly the attendance rate.

- To keep the students workload within the ECTS standards (i.e. 4-6 hours of non-contact work per week). 
- To stimulate students future interest in Structures.

\section{Instructional method}

To implement the Problem-based learning method in the course, it has been divided into 5 modules. In each module, the main teaching/learning activity is a problem, lasting approximately 3 weeks.

During the course, the students have to deal with 5 structural problems of rising complexity. In the tutorial sessions (one per week, two hours' duration), the students work in groups, discuss the problem and formulate learning issues for independent study (fig. 3).

\section{Assessment}

The course program was designed following the principle of constructive alignment (Biggs and Tang, 2007, p. 50) that is achieved by ensuring that both the learning activities and the assessment tasks are directly related to the learning outcomes of the course (fig. 4). In other words, if the main competence of the course is Project Structures, the students have to undertake a project, and we should assess the students' proficiency on the project.

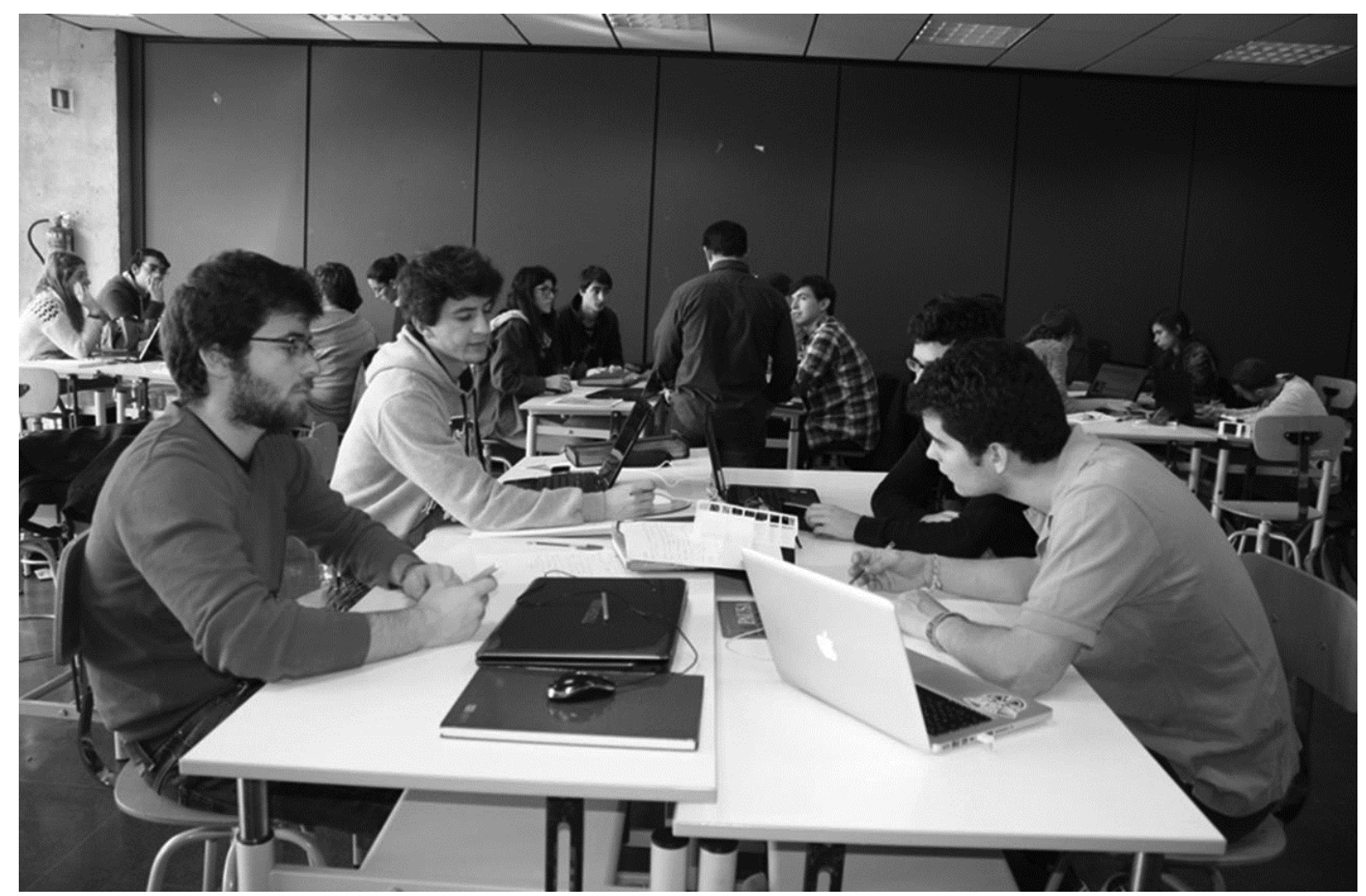

Fig. 3. Students in a tutorial session with roving tutor. 
Thus, the main assessment tasks are related to the problems, including an oral presentation and a written report, in sum weighting $85 \%$ of the final grade.

Also, two individual tests weighting $15 \%$ of the final grade are scheduled during the course. In each test, a problem similar to the main PBL problems of the course has to be tackled individually by the students. The tests are valuable to stress individual accountability. Students who fail the tests are prompted to undertake an oral defense of the final problem of the course.

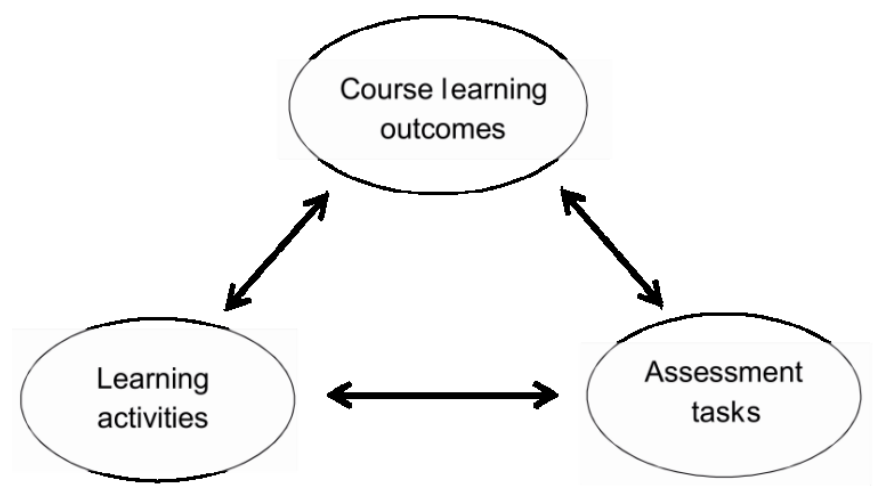

Fig. 4. Constructive alignment (Biggs and Tang, 2007)

\section{Course contents}

We have reformulated the contents of the course to adapt to the new learning environment. They are now structured in five modules and are based on what the students need to know to tackle the problems of the course. The theoretical material has been condensed, so it is not taught as an end in itself but rather as support for the problem at hand (Black and Duff, 1994, p. 42).

More specifically, we reduced hand calculation, focusing mainly in the analysis of statically determinate structures. The approach is now more qualitative, aimed primarily at understanding the concepts and principles of structural behavior. For a more detailed overview of the program, see Justo and Delgado (2010).

The course contents are organized in the following modules, of growing complexity:

- Module 1. Introduction to structural types.

- Module 2. Internal forces and deformation.

- Module 3. Design a beam for bending.

- Module 4. 2D analysis of a structure.

- Module 5. 3D design and analysis of a structure. 


\section{Course problems}

In the three years since the course was implemented, we have developed a number of problems, all relating to the analysis and design of structures in a real context. Fig. 5 shows an example of a problem statement in the current PBL structural engineering approach.

\section{STAHL HOUSE}

The Stahl House was completed in 1960 as part of the case study houses program, sponsored by Arts and Architecture magazine between the years 1945 and 1966, with the aim of exploring new ideas in house design and building after World War II. For inclusion in the program the houses should meet a number of requirements: to be affordable and efficient, to be capable of duplication and to be built and ready for occupation in 6-8 weeks. Public access should be allowed for a short period after completion.

Built at the top of Hollywood Hills, over Sunset Boulevard, the house features a swimming pool and a 270- degree panoramic view over the city extending below. It is, perhaps, the archetype house that represents the "good life" style from Southern California. Detailed examination of the ground floor shows that Koenig exploited the potential of such a problematic site to the maximum. He designed a moment resisting frame structure, resting on caissons foundation, locating one of the wings of the Lshape floor along the east-west axis to provide for a safe support on solid ground. At the end of the opposite wing is the living room, virtually flying over the Hollywood view.

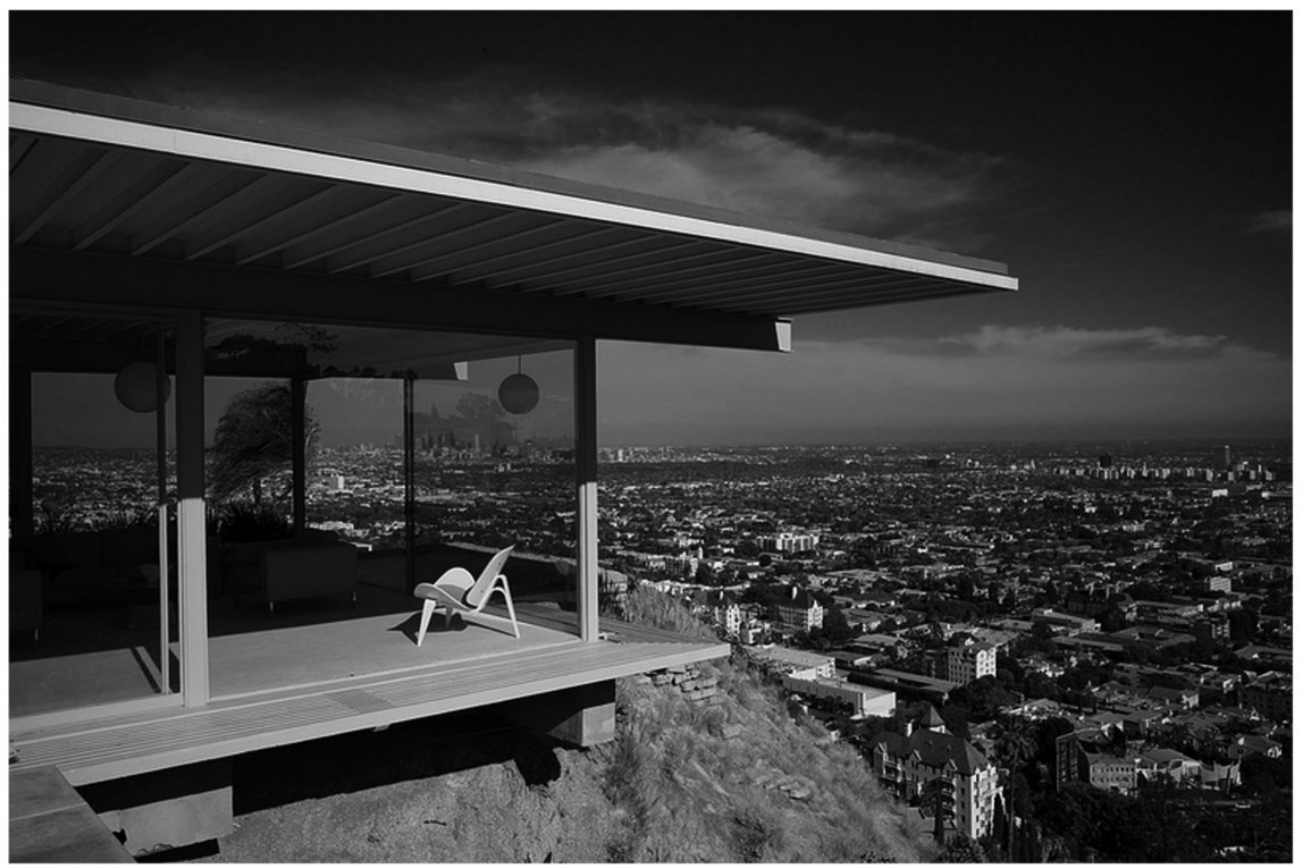

The group must undertake a study on the structural behavior of the Stahl house, including the following aspects:

- Initial sizing of structural members by hand calculation.

- Computer analysis of the primary structural system and secondary structural elements.

- Sizing of structural members.

- Description of the structural behavior of the house.

- Critical analysis of the structural design.

Fig. 5. Problem statement in the Structural Engineering PBL implementation. Photograph by Nicolas de Camaret. Licensed under Creative Commons Attribution 4.0 International License (creativecommons.org/licenses/by/4.0). 


\section{Program implementation}

We carried out a pilot experience in the course 2009-10, testing the implementation of the competence-based approach. The experience proved successful in terms of both academic results and students' satisfaction. In the course 2010-11, when the new Architecture degree was launched, we extended the PBL implementation to all students enrolled in the course Structures 1. In the course 2011-12, we implemented an improved version of the course, involving 12 groups with a total of 324 students. To collect feedback about the course implementation, a comprehensive evaluation plan was carried out, including faculty and students' surveys, faculty and students focus groups, and experts' judgments. The results of such evaluation allowed us to draw conclusions about program effectiveness, identifying strengths and weaknesses in order to define actions for improvement.

\section{Evaluation Results}

The evaluation of program effectiveness measures the degree to which the course objectives were attained. The degree of achievement of each objective is discussed in the following paragraphs.

\section{Students' achievement of course learning outcomes}

The course's learning outcomes are related to the development of the specific competence Structural Project. The effectiveness in the achievement of this objective is measured by two indicators:

a) Students' success rate.

b) Students' self-evaluation of learning.

The results regarding students' achievement are highly positive. The success rate (table 2) reaches $84.6 \%$, with a dropout rate as low as $8 \%$. 


\begin{tabular}{ll}
\hline Criteria & Value \\
\hline Enrolled students & 324 \\
\hline Passed & 274 \\
\hline Dropout & 26 \\
\hline Success rate & $84.6 \%$ \\
\hline Dropout rate & $8 \%$ \\
\hline
\end{tabular}

Table 2. Academic results in the course Structures 1 (PBL) in 2011-12.

The students' self-evaluation of learning is measured by the survey items in which the students are asked about their perception of learning. The results are listed in table 3, showing average scores between 3.62 and 3.94 (on a 1 to 5 scale) in the main learning outcomes of the course, which indicate a high perception of learning among students.

\begin{tabular}{llll}
\hline Learning outcomes & Mean & Standard dev. \\
\hline Identify the structural types... & 3.94 & .787 \\
\hline $\begin{array}{l}\text { Determine the values of the most } \\
\text { frequent actions... }\end{array}$ & 3.75 & .825 \\
\hline $\begin{array}{l}\text { Determine the behavior of a statically } \\
\text { determinate structure... }\end{array}$ & 3.86 & .847 \\
\hline Apply the limit states method... & 3.88 & .968 \\
\hline $\begin{array}{l}\text { Determine the behavior of a framework } \\
\text { structure... }\end{array}$ & 3.67 & .888 \\
\hline Analyze simple structures... & 3.88 & .869 \\
\hline Design simple structures... & 3.62 & .993 \\
\hline
\end{tabular}

Table 3. Students' self-evaluation of learning in the course expected learning outcomes (1 to 5 scale) 


\section{Students' acquisition of generic competences}

The acquisition of generic competences, such as team working skills, is an objective of the program. Nevertheless, proper evaluation of its achievement was not possible due to the lack of instruments in the course assessment system.

\section{Students and faculty satisfaction}

Students and faculty satisfaction were evaluated by the survey. Students rated their overall satisfaction with the course at 3.86 ( 1 to 5 ). In addition, the portion of students that are clearly unsatisfied (values lower than 3 in the scale) is as low as $6.1 \%$ (table 4).

Faculty survey also shows high levels of satisfaction with the course, with an average value of 4 , in a 1 to 5 scale.

\begin{tabular}{|c|c|c|c|}
\hline Value & Frequency & Percent & $\begin{array}{c}\text { Cumulative } \\
\text { percent }\end{array}$ \\
\hline 1 & 4 & 1.5 & 1.5 \\
\cline { 2 - 4 } 2 & 12 & 4.5 & 6.1 \\
\cline { 2 - 4 } 3 & 46 & 17.4 & 23.5 \\
\cline { 2 - 4 } 4 & 158 & 59.8 & 83.3 \\
\cline { 2 - 4 } 5 & 44 & 16.7 & 100.0 \\
\hline Total & 276 & 100 & \\
\hline
\end{tabular}

Table 4. Frecuency table of students 'satisfaction (1 to 5 scale)

\section{Class attendance}

Attendance rates have increased substantially, reaching a value of $84 \%$, which constitute an increase of more than $200 \%$ with respect to previous versions of the curriculum (see table 1).

\section{Students' workload}

According to the data collected by the students' survey, the average students' workload is 4.54 hours, which falls in the range of 4-6 hours, consistent with the ECTS standards.

\section{Faculty workload}

PBL has historically raised concerns about an increase in faculty workload (Albanese and Mitchell, 1993, p. 70), due mainly to an increase in the time devoted to course preparation, students' tutoring and assessment tasks, with respect to a lecture-based curriculum. In this case, the PBL course took an average of 5.1 faculty hours per week (aside from the class time), which is not an inordinate amount of time. Nevertheless the time commitment can 
still be considered too high, especially for part-time professors, and it is considered as a point for improvement in further implementations of the course.

\section{Conclusions}

Despite growing interest in competence-based education on the part of educators and institutions, its widespread adoption is still not a reality. To support such a paradigm shift, evaluations of existing practices in the field of engineering are useful. This paper examines the implementation of a competence-based approach by means of the Problem-based learning instructional method. We have proposed a program for a Structural Engineering course, focusing on competences development. The results from the program evaluation allow drawing conclusions about: a) program effectiveness and b) the benefits and challenges of such a paradigm shift.

\section{Program effectiveness}

In general terms, it can be concluded that the program is effective in the achievement of the proposed objectives, We achieved good results in terms of students' learning, students and faculty satisfaction and students' workload according to ECTS standards.

The assessment of generic competences has posed a major challenge. It has been noted that specific assessment tools must be provided in order to evaluate generic competences, such as problem solving or teamwork skills. A better integration of generic competences in the assessment system will: a) engage students in learning them and b) inform the teachers about the degree in which they are learned. As Barrows (1986, p. 485) points out, "evaluation determines the way in which students will study despite anything teachers may say about the goals of a course".

To pay them due attention, the number of generic competences to be developed in the course must be reduced, selecting the most relevant to the particular context of the course, which in this case are problem-solving and teamwork ability.

\section{Benefits}

One of the main advantages of the competences approach is the increase in students motivation. Our results show that students feel more engaged when they undertake real structural problems, in an architectural context. High motivation results in increased class attendance and lower drop-out rate. Similarly, group work is also a key factor in students' 
engagement, as a result of positive interdependence (Johnson et al. 2006, p. 17) within the group.

Besides promoting motivation, the nature of the problems tackled also led to a better integration of structural concepts into a broader context of architectural design, making connections with the knowledge of other disciplines. This is the aim of all architecture programs, and it has also been found very positive by students and faculty.

The suitability for learning generic competences is another benefit of the PBL approach. Process skills (as teamwork or problem solving skills) are considered in the new Architecture or Engineering curriculums as being equally important as subject knowledge, but they could be hardly tackled in a lecture-based approach.

\section{Challenges}

The increase in faculty time commitment has been a drawback in the PBL implementation. Nevertheless, it doesn't appear to have had a significant impact in faculty members' satisfaction, which is still high. Concerning faculty workload, class size is no doubt a critical factor. In the case of study, a class size of 25-30 students have made it possible the PBL implementation keeping faculty effort within reasonable limits. For larger classes the feasibility of the PBL approach may raise serious concerns. It must not be forgotten that the PBL method was conceived for small groups of 8-10 students, with a tutor per group.

In the field of Engineering, where there is a rooted tradition of lectures and examinations, a change of this magnitude in the model for education will pose a major challenge for faculty and students. On the part of the faculty, the new method also required a shift from the role of instructor to that of facilitator, which entails the learning of new teaching skills.

Concerning the course design, a significant effort had to be made in rethinking the way the discipline knowledge is to be learned. The learning of competences leads naturally to an actualization of knowledge and methods, bringing them closer to professional practice. In the case of Structural Engineering it meant, for example, relying more on computer analysis or integrating calculations within the design process.

Particular attention should be given to alignment between the course learning outcomes and assessment tasks. The tendency among faculty members to rely primarily on written examinations for assessment purposes should be overcome, since it may negatively affect students' engagement in the course activities. 
With due account of the aspects outlined, extrapolation to other disciplines is possible. It will require in the first place a careful definition of the course objectives in terms of competences and learning outcomes, and in the second place a profound rethinking of the subject knowledge and methods of the target discipline.

\section{References}

ABET (1997). "Engineering Criteria 2000, Third Edition: Criteria for Accrediting Programs in Engineering in the United States." The Accreditation Board for Engineering and Technology. Baltimore, Maryland.

Albanese, M. A., and Mitchell, S. (1993). "Problem-based learning: A review of literature on its outcomes and implementation issues." Academic Medicine, 68(1), 52-81.

Aleamoni, L. M. (1999). "Student rating myths versus research facts from 1924 to 1998." Journal of Personnel Evaluation in Education, 13(2), 153-166.

ANECA (2005). "Libro blanco del título de grado en Arquitectura." Agencia Nacional de Evaluación de la Calidad y Acreditación.

Barrows, H. S. (1986). "A taxonomy of problem-based learning methods." Medical Education, 20(6), 481-486.

Barrows, H. S., and Tamblyn, R. M. (1980). “Problem-based learning: An approach to medical education." New York: Springer Publishing Company.

Beddoes, K. D., Jesiek, B. K., and Borrego, M. (2010). "Identifying Opportunities for Collaborations in International Engineering Education Research on Problem and ProjectBased Learning." Interdisciplinary Journal of Problem-based Learning, 4(2), 7-34.

Biggs, J., \& Tang, C. (2007). "Teaching for quality learning at university: What the student does (3rd edition)." Open University Press, Buckingham, UK.

Black, R. G., \& Duff, S. (1994). "A model for teaching structures: Finite element analysis in architectural education." Journal of Architectural Education, 48(1), 38-55.

De Graaff, E., \& Kolmos, A. (2003). "Characteristics of problem-based learning." International Journal of Engineering Education, 19(5), 657-662.

Dolmans, D. H., De Grave, W., Wolfhagen, I. H., \& Van Der Vleuten, C.P.M. (2005). "Problembased learning: Future challenges for educational practice and research." Medical Education, 39(7), 732-741. 
European Commission (2009). "ECTS user's guide."

http://ec.europa.eu/education/tools/docs/ects-guide_en.pdf $\rangle$ (Feb. 9, 2014).

Felder, R. M., Woods, D. R., Stice, J. E., and Rugarcia, A. (2000). "The future of engineering education II. Teaching methods that work." Chemical Engineering Education, 34(1), 26-39.

Felder, R. M., \& Brent, R. (2003). Designing and teaching courses to satisfy the ABET engineering criteria. Journal of Engineering Education, 92(1), 7-25.

Fernández-Sánchez, G., and Millan, M. A. (2013). "Structural Analysis Education: Learning by "hands-on" projects and calculating structures." Journal of Professional Issues in Engineering Education and Practice. 139(3), 244-247.

Goldfinch, T. L., Carew, A. L. and McCarthy, T. J. (2008). "Improving Learning in Engineering Mechanics: The Significance of Understanding." In L. Mann, A. Thompson P. Howard (Eds.), AAEE - Annual Conference of Australasian Association for Engineering Education, 1-6. Rockhampton, QLD.

Gonzalez, J. and Wagenaar, R. (Ed.). (2003). "Tuning educational structures in Europe. Final report. Phase one." University of Deusto, Bilbao, Spain.

Johnson, D. W., Johnson, R. T., \& Smith, K. A. (2006). "Active learning: Cooperation in the college classroom (8th ed.)." Interaction Book Company, Edina, MN.

Justo, E. and Delgado, A., (2010). "Proyecto docente de la asignatura Estructuras 1 del grado en Arquitectura por la Universidad de Sevilla."

<http://gdus.us.es/proyectos20132014/2330007_9343_37838.pdf>.

Kirschner, P. A., Sweller, J., \& Clark, R. E. (2006). Why minimal guidance during instruction does not work: An analysis of the failure of constructivist, discovery, problem-based, experiential, and inquiry-based teaching. Educational Psychologist, 41(2), 75-86.

Ministerio de Educación, Cultura y Deporte (2007). "Real decreto 1393/2007, de 29 de octubre, por el que se establece la ordenación de las enseñanzas universitarias oficiales." Boletín Oficial del Estado, 30, 44037-44048.

Mosalam, K. M., Hube, M. A., Takhirov, S. M., and Günay, S. (2013). "Teaching Innovation through Hands-on-Experience Case Studies Combined with Hybrid Simulation." Journal of Professional Issues in Engineering Education and Practice. 139(3), 177-186. 
Pedron, C. (2006). "An innovative tool for teaching structural analysis and design." Institute of Structural Engineering, Suisse Federal Institute of Technology (IBK), Report No. 298, Zurich, Switzerland.

Prados, J. W., Peterson, G. D., and Lattuca, L. R. (2005). "Quality assurance of engineering education through accreditation: The impact of Engineering Criteria 2000 and its global influence." Journal of Engineering Education, 94(1), 165-184.

Prince, M. (2004). "Does active learning work? A review of the research." Journal of Engineering Education. 93(3), 223-231.

Quinn, K. A., \& Albano, L. D. (2008). Problem-based learning in structural engineering education. Journal of Professional Issues in Engineering Education and Practice, 134(4), 329334.

Savery, J. R., and Duffy, T. M. (1995). "Problem based learning: An instructional model and its constructivist framework." Educational Technology, 35, 31-38.

Savin-Baden, M. (2000). "Problem-based learning in higher education: Untold stories." Society for Research into Higher Education, London, UK.

Schmidt, H. G., Rotgans, J. I., \& Yew, E. H. (2011). "The process of problem-based learning: what works and why." Medical education, 45(8), 792-806.

Solís, M., Romero, A., \& Galvín, P. (2012). Teaching structural analysis through design, building and testing. Journal of Professional Issues in Engineering Education and Practice, 138(3), 246-253.

Svinicki, M. D. (2007). "Moving beyond "it worked": The ongoing evolution of research on problem-based learning in medical education." Educational Psychology Review, 19(1), 49-61. Uden, L., and Beaumont, C. (2006). "Technology and problem-based learning." Information Science Publishing, London, UK.

Van Barneveld, A., and Strobel, J. (2009). "Problem-based learning: Effectiveness, drivers, and implementation challenges." In X. Du, E. De Graaff \& A. Kolmos (Eds.), Research on PBL practice in engineering education, Sense Publishers, Rotterdam, Netherlands, 35-44.

Walker, A., and Leary, H. (2009). "A problem-based learning meta-analysis: Differences across problem types, implementation types, disciplines, and assessment levels." Interdisciplinary Journal of Problem-Based Learning, 3(1), 12-43. 
Westera, W. (2001). "Competences in education: a confusion of tongues". Journal of Curriculum Studies, 33(1), 75-88. 